\title{
MANAJEMEN PENGEMBANGAN KULTUR LITERASI DI MTs NEGERI KOTA BATU
}

\author{
Nurlaeli Fitriah \\ Universitas Islam Negeri Maulana Malik Ibrahim Malang \\ Email: nurlaily.fitriah@uin-malang.ac.id
}

\begin{abstract}
Literacy is identified with reading and writing activities. With the passage of time literacy activities not only read and write. Literacy is defined as the ability to support, challenge, create, communicate and count using printed material and writing related to various contexts. Literacy that supports learning is literacy that allows individuals to achieve what they want to know, develop their knowledge and talents and support their participation in the community. This study aims to describe the management of the development of literacy culture, the implementation of the development of a culture of literacy and the evaluation of literacy culture development programs in MTs Negeri Kota Batu. This research uses qualitative with descriptive research types. The data sources used are primary and secondary. Data analysis used the Miles and Huberman analysis models. The results show the management carried out by the MTs Negeri Kota Batu under the coordination of the kepala madrasah and supported by the deputy of kepala madrasah in the fields of curriculum, infrastructure, public relations and financing. Not only that, for the success of the school management program, it also involves the madrasah committee. The implementation of the program in the form of habituating the dhuha prayer and reading Al-Qur'an, the habit of silent reading before learning, holding reading corners, programming the language of the month, and scientific writing training for teacher in collaboration with universities in Malang. Program evaluation carried out by the madrasah management is still anticipatory action. Its consideration is that the program is just implemented.
\end{abstract}

Keywords. Education Management, Literacy Culture, Madrasah

Abstrak. Literasi diidentikkan dengan aktivitas membaca dan menulis. namun dengan berjalannya waktu kegiatan literasi tidak hanya sekedar membaca dan menulis saja. Literasi (melek huruf) diartikan sebagai kemampuan untuk mengidentifikasi, memahami, menafsirkan, membuat, berkomunikasi dan menghitung dengan menggunakan bahan cetak dan tulisan yang terkait dengan berbagai konteks. Literasi melibatkan serangkaian pembelajaran yang memungkinkan individu mencapai tujuannya, mengembangkan pengetahuan dan potensinya serta berpartisipasi dalam komunitas masyarakat. Penelitian ini bertujuan untuk mendeskripsikan manajemen pengembangan kultur literasi, implementasi pengembangan kultur literasi dan evaluasi yang dilakukan terhadap program pengembangan kultur literasi yang ada di MTs Negeri Kota Batu. Penelitian ini menggunakan pendekatan kualitatif dengan jenis penelitian deskriptif. Sumber data yang digunakan adalah primer dan sekunder. Analisis data menggunakan model analisis Miles and Huberman. Hasil menunjukkan bahwa pengelolaan yang dilakukan oleh MTs Negeri Batu dibawah koordinasi kepala madrasah dan dibantu oleh para wakil kepala pada bidang kurikulum, sarana prasana, humas dan juga pembiayaan. Tidak hanya itu, untuk menyukseskan program manajemen madrasah juga melibatkan komite sekolah. Pelaksanaan program dalam bentuk pembiasaan 
shalat dhuha dan membaca al-Qur'an, pembiasaan membaca senyap sebelum pembelajaran, mengadakan pojok-pojok baca, memprogramkan bulan bahasa, dan mengagendakan pelatihan penulisan karya ilmiah bekerjasama dengan perguruan tinggi yang ada di Malang Raya. Evaluasi program yang dilakukan oleh pihak manajemen madrasah masih bersifat antisipatif dengan pertimbangan bahwa program masih baru berjalan.

Kata Kunci. Manajemen Pendidikan, Kultur Literasi, Madrasah.

Copyright (C) JMPI: Jurnal Manajemen Pendidikan Islam. All Right Reserved.

This is an open access article under the CC BY-NC-ND license

(http:/ / creativecommons.org/licenses/by-nc-nd/4.0/).

\section{A. PENDAHULUAN}

Literasi dalam pembelajaran abad 21 menjadi bagian dari kajian utama dalam proses pelaksanaannya. Dalam kurikulum 2013 edisi revisi pembelajaran diarahkan pada penguatan literasi dalam pelaksanaannya. Literasi diidentikkan dengan aktivitas membaca dan menulis. namun dengan berjalannya waktu kegiatan literasi tidak hanya sekedar membaca dan menulis saja. Literasi, dalam bahasa inggris literacy, berasal dari bahasa latin littera (huruf) yang pengertiannya melibatkan penguasaan sistem-sistem tulisan dan konvensi-konvensi yang menyertainya. Pengertian literasi berdasarkan konteks penggunaanya merupakan integrasi keterampilan menyimak, berbicara, menulis, membaca, dan berpikir kritis (Baynham, 1995). Pendapat lainnya bahwa literasi merupakan sesuatu yang kompleks dan dinamis yang lebih dari sekedar kemampuan baca tulis. Di dalamnya terdapat praktik-praktik situasi sosial dan historis serta berkaitan dengan kultur dalam rangka menciptakan dan memaknai (Kern, 2000). Literasi (melek huruf) diartikan sebagai kemampuan untuk mengidentifikasi, memahami, menafsirkan, membuat, berkomunikasi dan menghitung dengan menggunakan bahan cetak dan tulisan yang terkait dengan berbagai konteks. Literasi melibatkan serangkaian pembelajaran yang memungkinkan individu mencapai tujuannya, mengembangkan pengetahuan dan potensinya serta berpartisipasi dalam komunitas masyarakat (UNESCO 2005). Oleh karena itu jelas sekali dikatakan bahwa literasi memiliki makna yang lebih luas daripada sekedar kemampuan membaca dan menulis saja. Lebih dari pada itu di dalamnya ada proses yang akan mengantarkan seseorang menjadi melek huruf kemudian memiliki kemampuan dan juga menggunakan kemampuan tersebut untuk mencapai tujuan dan mengembangkan potensinya dalam masyarakat luas.

Hasil penelitian yang dilakukan oleh Most Littered Nation In the World tahun 2016 bahwa minat baca anak Indonesia berada pada posisi 60 dari 61 negara. Menurut Subekti Makdriani, Pustakawan Perpustakaan Republik Indonesia, salah satu factor yang mempengaruhi menurunnya minat baca ini adalah semakin berkembangnya teknologi terutama teknologi komunikasi digital (Tribunnews, 2017). Pemerintah melakukan berbagai upaya salah satunya adalah melalui gerakan literasi sekolah.

Hasil penelitian PIRLS 2006 di 45 negara menunjukkan bahwa anak yang berasal dari keluarga yang sadar literasi anak sejak dini memiliki kemampuan literasi yang lebih tinggi (Mullis, Martin, Kennedy, \& Foy, 2007). Sehingga bisa 
dikatakan bahwa faktor lingkungan sangat berkontribusi dalam pengembangan kemampuan literasi anak. Lingkungan anak usia sekolah adalah lingkungan di rumah dan di lingkungan sekolah. Lingkungan rumah memberikan kontribusi pengembangan kemampuan literasi melalui kesadaran orang tua terhadap literasi. Sedangkan lingkungan sekolah memberikan kontribusi melalui komponen pendidikan yang ada di sekolah.

Gerakan literasi sekolah adalah program yang digalakkan pemerintah melalui kementerian Pendidikan dan Kebudayaan. Gerakan Literasi Sekolah adalah gerakan menyeluruh yang melibatkan seluruh warga sekolah dan masyarakat. Gerakan Literasi Sekolah sebagai upaya penumbuhan budi pekerti sebagaimana tertuang dalam Permendikbud nomor 23 tahun 2015 (Wiedarti, 2016). Gerakan Literasi Sekolah merupakan bagian dari pengembangan kemampuan literasi melalui kontribusi lingkungan sekolah. Sebagaimana kita ketahui komponen lingkungan sekolah ini meliputi lingkungan fisik dan lingkungan sosial (Kristiawan, 2017). Baik lingkungan fisik maupun lingkungan sosial sangat dibutuhkan untuk mendukung atmosfir literasi yang harapannya akan menumbuhkan kultur literasi.

Menumbuhkan kultur literasi dalam gerakan literasi sekolah memang telah menjadi bagian pengembangan yang dilakukan sekolah. Demikian pula di MTs Negeri Kota Batu. MTs Negeri yang terletak adalah madrasah yang berada di kota wisata batu. Sebuah kota yang dikenal sebagai salah satu kota wisata di Indonesia yang menjadi rujukan para wisatawan baik domestik maupun luar negeri. Kota wisata memang banyak menjanjikan income bagi daerah namun juga rentan terhadap pengaruh kultur yang datangnya dari luar daerah yang dibawa oleh para wisatawan. Perlu adanya antisipasi yang serius terutama dalam dunia pendidikan untuk menangkal pengaruh negatif yang datangnya dari luar. Kecenderungankecenderungan yang mengarah kepada perubahan kultur sangat mungkin sekali terjadi.

Berbagai upaya dilakukan agar kultur literasi yang diharapkan dapat tumbuh kembali di kalangan siswa khususnya dan ekosistem madrasah tersebut pada umumnya. Tentu saja upaya yang dilakukan memerlukan pengelolaan yang baik agar program apapun yang dicanangkan dapat mendukung terciptanya kultur literasi sebagaimana program pemerintah dalam pendidikan. Pengelolaan yang dilakukan madrasah ini tidak semuanya secara langsung ditujukan bagi siswa namun dalam pelaksanaannya seluruh komponen pada madrasah baik eksternal maupun internal turut mengambil bagian.

\section{B. METODE}

Penelitian ini menggunakan pendekatan kualitatif dengan jenis penelitian deskriptif. Sumber data yang digunakan adalah primer dan sekunder. Metode pengumpulan data menggunakan teknik wawancara, observasi dan dokumentasi. Teknik wawancara untuk mendapatkan informasi tentang manajemen, implementasi dan evaluasi yang dilakukan dalam pengembangan kultur literasi. Dengan teknik observasi diperoleh informasi yang berkaitan dengan aktivitas yang berkaitan dengan pengembangan kultur literasi. Melalui teknik dokumentasi dilakukan untuk mentelaah dokumen-dokumen yang terkait dengan tema penelitian. Analisis data menggunakan model analisis Miles and Huberman. 


\section{HASIL DAN PEMBAHASAN}

\section{Manajemen Pengembangan Literasi}

Manajemen berasal dari bahasa latin dari kata "manus" yang artinya tangan dan "agere" yang artinya melakukan. Kemudian kedua kata ini digabungkan menjadi "managere" yang artinya menangani sesuatu, mengatur, membuat sesuatu menjadi sesuai keinginan dengan mendayagunakan seluruh kemampuan dan sumber daya yang ada (Kristiawan, 2017). Berdasarkan makna yang disebutkan di atas dapat dikatakan manajemen berhubungan dengan kegiatan pengelolaan untuk mencapai tujuan yang diinginkan. Tujuan yang telah ditetapkan dijadikan tolok ukur keberhasilan sebuah pengelolaan yang dilakukan. Jika tujuan tercapai berarti pengelolaan yang dilakukan telah terlaksana dengan baik.

Membangun kembali budaya literasi di kalangan generasi muda memang bukanlah perkara mudah. Lunturnya budaya literasi yang ada di masyarakat kita memang banyak mempengaruhi perilaku pendidikan generasi muda. Begitu besarnya pengaruh lingkungan terhadap perilaku literasi terutama pada siswa sekolah di segala jenjang pendidikan. Tidak jauh berbeda dengan kondisi yang ada di MTs Negeri Kota Batu. Apalagi kota Batu adalah kota wisata yang sangat rentan dengan pengaruh yang datangnya dari luar. Yang baik langsung maupun tidak langsung turut mempengaruhi perilaku masyarkatnya. Gerakan literasi sekolah menjadi upaya antisipasi yang dilakukan oleh madrasah dalam rangka menumbuhkan kembali kultur literasi pada generasi muda khususnya siswa di madrasah tersebut.

Berbicara tentang pelaksanaan sebuah program kegiatan tentu tidak akan terlepas dari peran pengelola madrasah. Pengelola madrasah terdiri dari kepala madrasah dan dibantu oleh 4 wakil kepala bidang. Sebagai top managemen kepala madrasah bertanggung jawab terhadap keberhasilan program pengembangan yang dicanangkan di madrasah. Demikian pula dengan program pengembangan budaya literasi di madrasah ini. Segala upaya dan program yang dilakukan di madrasah ini diarahkan pada pemenuhan 8 standar pendidikan nasional. Delapan standar pendidikan nasional tersebut meliputi Standar Kompetensi Lulusan, Standar Isi, Standar Proses, Standar Pendidikan dan Tenaga Kependidikan, Standar Sarana dan Prasarana, Standar Pengelolaan, Standar Pembiayaan Pendidikan, Standar Penilaian Pendidikan. Program pengembangan budaya literasi yang dilaksanakan di madrasah ini diupayakan dapat mendukung terpenuhinya 8 standar pendidikan nasional tersebut secara optimal baik langsung maupun tidak langsung karena hal ini berkaitan langsung dengan sistem pengelolaan yang dilakukan. Keterkaitan antara berbagai komponen dalam seluruh 8 standar pendidikan nasional akan menjadi penunjang dan indikator keberhasilan dari pelaksanaan sebuah program.

Salah satu contoh adalah bahwa budaya literasi berkaitan langsung dengan sumber daya yang ada. Sumber daya manusia yang ada di dalamnya sebagai pelaku utama ditunjang oleh sarana prasarana yang memadai, struktur kurikulum yang tertata dengan sistematis dan menyeluruh, dan didukung oleh dana pembiayaan yang cukup akan memberikan peluang yang sangat besar bagi keberhasilan program pengembangan literasi yang dicanangkan. Beers menyampaikan beberapa strategi yang dapat digunakan dalam pengembangan budaya literasi di sekolah seperti 
mengkondisikan lingkungan fisik yang ramah literasi, mengupayakan lingkungan afektif dan sosial sebagai model komunikasi dan interaksi yang literat, serta mengupayakan lingkungan akademik yang literat (Beers, Beers, \& Smith, 2009).

Pengelolaan terhadap pengembangan kultur literasi di MTs Negeri Kota Batu di lakukan melalui proses perencanaan yang telah dikoordinasikan kepala madrasah dibantu 4 wakilnya. Beberapa kegiatan direncanakan dalam mendukung pengembangan kultur literasi di madrasah ini dengan mengimplementasikan strategi-strategi yang mendukung terwujudnya kultur literasi sebagaimana disebutkan sebelumnya. Kegiatan-kegiatan tersebut antara lain pembiasaan shalat dhuha dan membaca al-Qur'an, pembiasaan membaca senyap sebelum pembelajaran, mengadakan pojok-pojok baca, memprogramkan bulan bahasa, dan mengagendakan pelatihan penulisan karya ilmiah bekerjasama dengan perguruan tinggi yang ada di Malang Raya. Setiap wakil kepala sekolah membantu koordinasi kegiatan sesuai dengan bidang garapannya masing-masing. Demikian juga dengan pelaksanaan kegiatan tersebut, setiap wakil kepala bertanggung jawab kepada kepala madrasah sebagai penanggung jawab program di madrasah. Seluruh program kegiatan disosialisasikan kepada seluruh sivitas madrasah dengan harapan target tercapai optimal.

Tidak hanya itu, kepala madrasah juga mengakomodir masukan pihak eksternal seperti komite madrasah. Program apapun yang diselenggarakan sekolah selalu disosialisasikan kepada komite madrasah. Komite madrasah adalah komite yang dibentuk oleh para wali murid di madrasah ini. Kontribusi komite madrasah dalam rangka turut menyukseskan program ini adalah selain berupa sosialisasi dalam keluarga masing-masing juga berupa dukungan dana. Dukungan dana ini dapat berupa dana iuran dari wali murid yang rutin dikumpulkan maupun dana yang sifatnya sumbangan pribadi oleh wali murid.

\section{Implementasi Program Pengembangan Budaya Literasi di MTs Negeri Kota Batu}

Program pengembangan budaya literasi yang dilaksanakan di MTs Negeri Kota Batu meliputi berbagai kegiatan yaitu:

a. Wajib Dhuha dan Membaca Al-qur'an

Kegiatan shalat dhuha dan membaca al-qur'an memang bukanlah hal yang baru di madrasa ataupun sekolah umum. Beberapa madrasah dan sekolah dengan background pendidikan islam memang memrogramkan shalat dhuha dalam program rutin pendidikannya. Namun demikian MTs Negeri Kota Batu memberikan penekanan lebih dengan mencantumkan kegiatan ini di dalam pembuatan jadwal. Dalam jadual mata pelajaran sekolah dicantumkan bahwa shalat dhuha adalah bagian dari kegiatan belajar di madrasah. Kegiatan ini menggunakan pembiasaan sebagai pendekatannya agar pembiasaan yang diberikan dapat menjadi perilaku/behavior yang nantinya menjadi budaya/kebiasaan yang sifatnya otomatis dikerjakan tanpa harus disuruh lagi. Pembiasaan semacam ini dalam teori prilaku disebut dengan pengkondisian klasik yang dikemukakan oleh Ivan Pavlov (E.Waruwu, 2010). Menurut teori ini bahwa pembiasaan dapat membentuk prilaku. Kegiatan ini rutin dilakukan setiap hari. Dalam kegiatan ini juga siswa juga diinstruksikan untuk berwudhu dari rumah. Pembiasaan semacam ini dilakukan 
agar siswa sudah terlatih menjaga wudhu. Ada tujuan tersirat dari instruksi ini yaitu agar siswa menjaga diri dari perbuatan-perbuatan negatif

Setelah shalat dhuha dilanjutkan dengan membaca al-Qur'an selama 20 menit sebelum pembelajaran di mulai. Kegiatan ini mewajibkan siswa di kelas masing masing membaca al Qur' an di dampingi oleh guru yang mengajar pada jam pertama. Pembiasaan-pembiasaan yang dilakukan tersebut dalam rangka untuk menumbuhkan kultur literasi pada siswa.

\section{b. Membaca senyap}

Dalam kurikulum juga diselipkan kegiatan literasi yaitu mencantumkan 1 jam pelajaran wajib baca yang di dampingi oleh wali kelas ke dalam jadual pelajaran. Wali kelas bekerja sama dengan kepala perpustakaan memberikan 1 buku kecil yang dipergunakan untuk merangkum hasil baca. Setiap bulannya semua siswa wajib mengumpulkan buku kecil tersebut di perpustakaan.

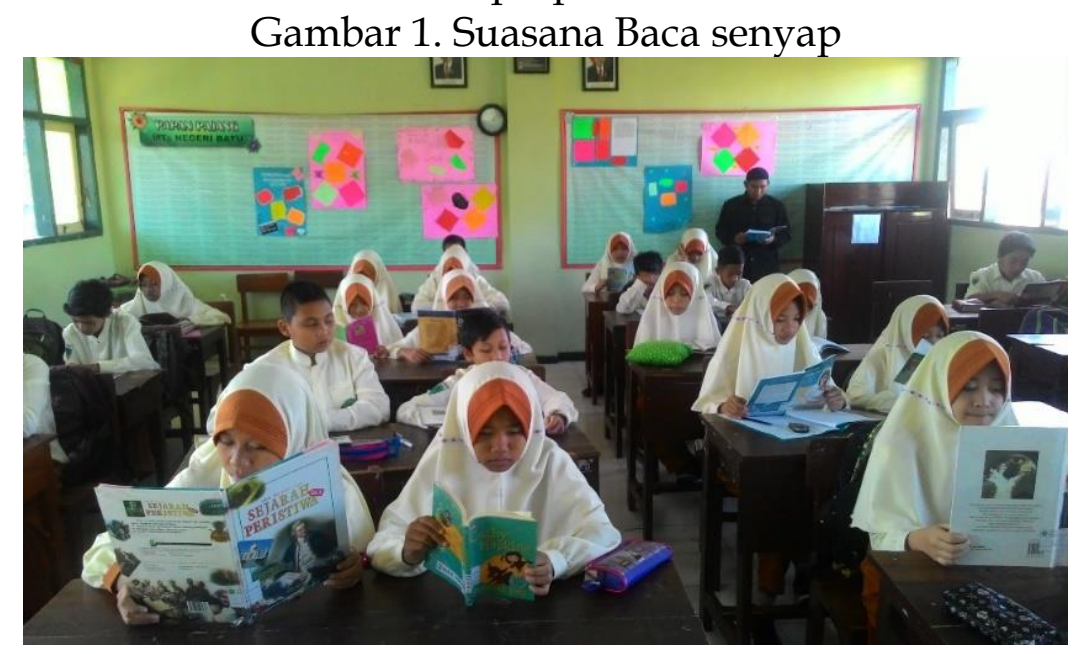

c. Mengadakan pojok-pojok baca

Mendukung terwujudnya kultur literasi waka kurikulum bekerjasama dengan waka prasarana membuat lemari pojok baca, mading di tempat tempat strategis dan papan kreasi di setiap kelas. Pojok baca diadakan untuk menarik minat siswa untuk membaca sedangkan mading dan papan kreasi diadakan untuk memajang hasil karya kreasi siswa.

Gambar 2. Rak Pojok Baca

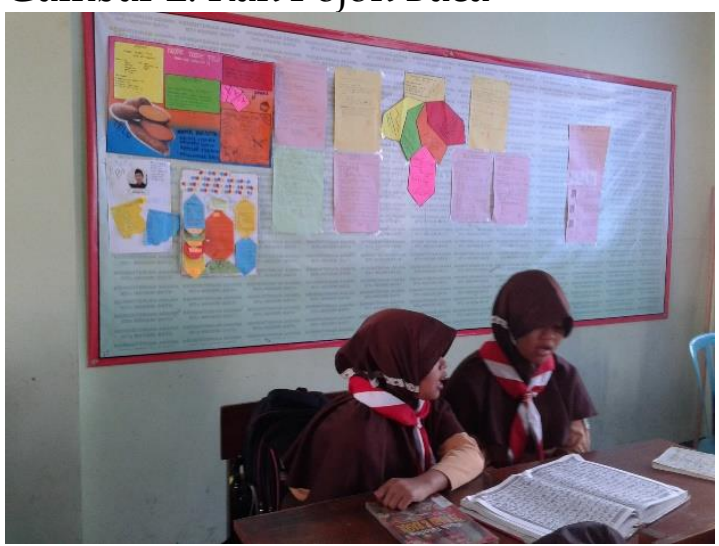

Gambar. 3 Papan Pajang

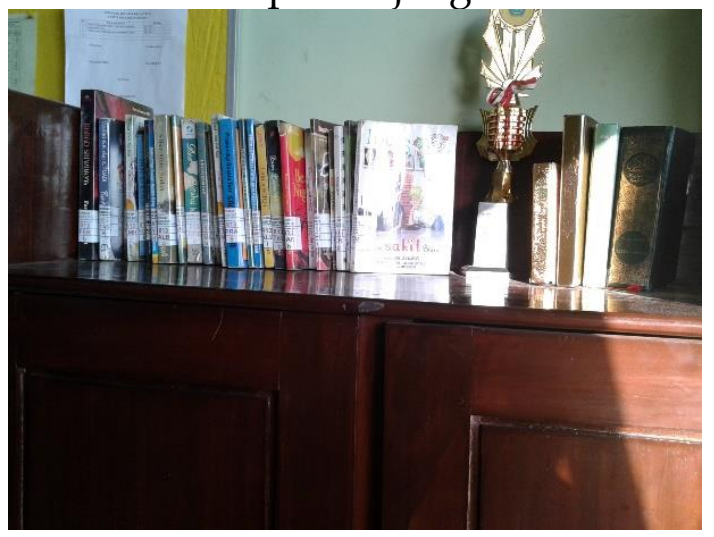




\section{d. Program Bulan Bahasa}

Program Bulan Bahasa adalah program yang dicanangkan untuk menyalurkan bakat dan minat siswa. Program ini adalah program kerjasama antara waka kurikulum, waka kesiswaan dan kepala perpustakaan. Program bulan bahasa yang dikemas dalam kegiatan class meeting berupa kegitan-kegiatan pilihan seperti menulis, menggambar, lagu, nasyid, mengaji, kreasi foto, puisi, pembuatan bahan daur ulang, olah raga dan lain lain. Kegiatan ini biasanya dilakukan pada akhir semester.
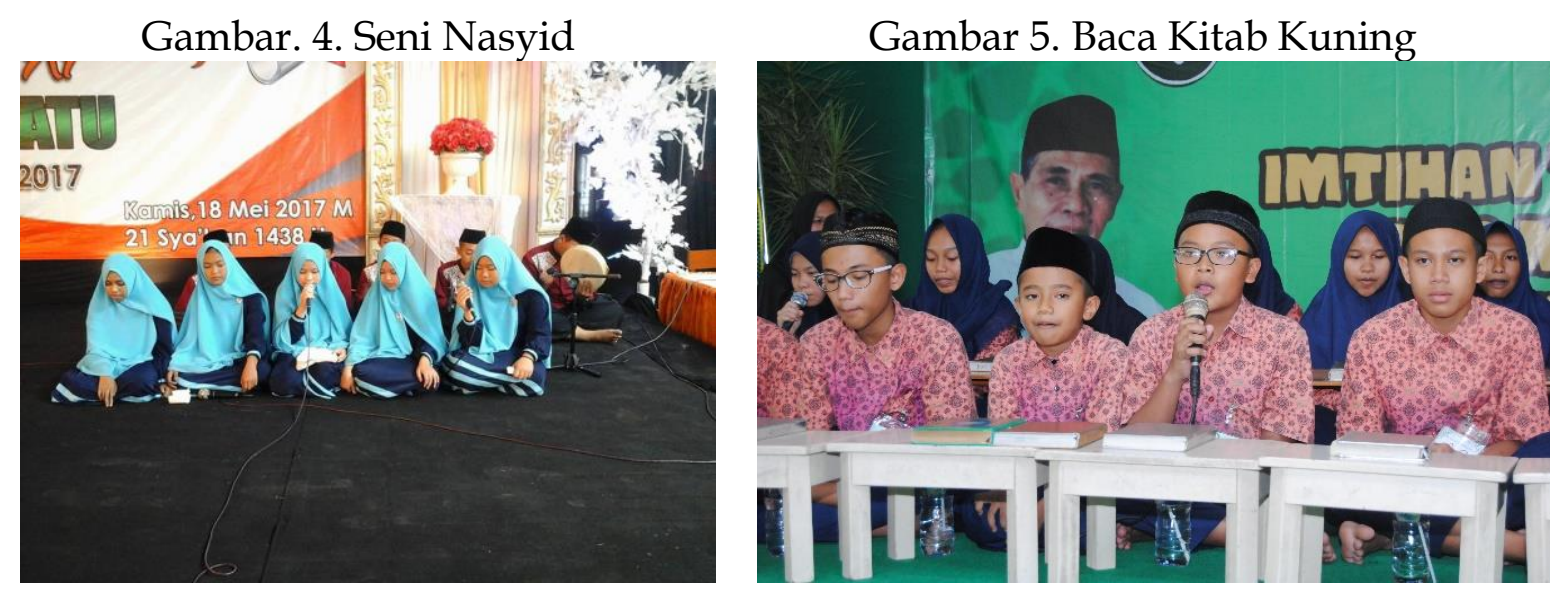

e. Pelatihan penulisan karya ilmiah bekerjasama dengan perguruan tinggi yang ada di Malang Raya seperti UIN atau ke UM.

Kegiatan lainnya yang dilakukan dalam rangka mendukung program pengembangan kultur literasi adalah kegiatan pelatihan penulisan karya ilmiah. Madrasah bekerjasama dengan perguruan tinggi yang ada di Malang Raya untuk mendukung kegiatan ini. Tidak hanya sekedar kemampuan melakukan penelitian oleh guru yang menjadi fokusnya tetapi juga melalui kegiatan ini guru lebih memiliki kemampuan yang cukup untuk dapat mendampingi siswa yang memiliki bakat dan minat dalam penulisan karya ilmiah

\section{Evaluasi Program Pengembangan Kultur Literasi di MTs Negeri Kota Batu}

Pengelolaan sebuah program idealnya tidak terlepas dari kegiatan evaluasi. Evaluasi adalah bagian penting dari sebuah program kegiatan. Stufflebeam menyatakan bahwa "Evaluation is a vital component of the continuing health of organizations. If evaluations are conducted well, organizations and their people will have the satisfaction of knowing with confidence which elements are strong and where changes are needed. Evaluation is therefore a constructive pursuit" (Madaus, Scriven, \& Stufflebeam, 2012). Jika ingin mendapatkan hasil yang memuaskan maka sebuah organisasi apapun pelu untuk melakukan evaluasi. Bukan hanya sekedar memperoleh informasi tentang hasil dari kegiatan tetapi juga keberlangsungan dari sebuah kegiatan.

Pelaksanaan literasi di MTsN Batu masih dalam tahap awal sehingga tidak seluruhnya berjalan sempurna. Evaluasi program yang dilakukan meskipun masih sederhana dilakukan untuk mengidentifikasi kekurangan dan kemudian dilakukan tindak lanjut. Evaluasi ini dikordinasikan oleh kepala madrasah dengan masing- 
masing wakil kepala untuk menggali kelebihan dan kelemahan. Berikut adalah beberapa hasil evaluasi yang dilakukan :

a. Upaya pembiasaan shalat dhuha berjamaah telah berjalan efektif. Hanya upaya pembiasaan wudhu dari rumah dan menjaga wudhu belum dapat dilaksanakan dengan intens karena memang hal-hal yang membatalkan wudhu masih belum dapat dihindari. Namun demikian tujuan utama agar siswa menjaga diri dari perbuatan negatif tetap menjadi perhatian.

b. Siswa dalam membaca kurang fokus, suasanakelas yang ramai ketika tidak ada wali kelas yang tidak masuk, hasil rangkuman siswa yang tidak optimal bahkan ada yang tidak menulis hasil apa yang dibaca. Ini semua terjadi karena menurut siswa buku yang diberikan perpustakaan kurang menarik dan kesadaran untuk menjaganya kurang.

c. Penggunaan mading yang siklus/pergantiaan tulisan belum terjadwal dengan baik, perlu keterlibatan siswa agar muncul rasa memiliki dan motivasi untuk mengisi dan menggunakan mading. Penggunaan papan pajang juga kurang optimal dikarenakan belum semua guru memanfaatkan dan melaksanakan pembelajaran yang memancing kreativitas siswa.

d. Pada kegiatan bulan bahasa dan class meeting belum semua siswa ikut tampil dalam pelaksanaan ini karena yang dilombakan masih berdasarkan perwakilan kelas. Perlu untuk lebih dikembangkan lagi alternatif lomba untuk menyalurkan bakat dan minat siswa

e. Pelaksanaan pembiasaan menulis bagi guru memang cukup berat karena memang tidak semua guru menganggap menulis itu penting. Ditambah lagi dengan beban kerja sebagai guru sekarang ini sangat padat. Kebayakan guru hanya semangat diawal kegiatan pelatihan saja setelah itu disibukkan dengan kegiatan terkait pengajaran setelah itu semangat itu hilang kembali.

Evaluasi yang dilakukan oleh pengelola madrasah memang masih pada tahapan menggali kekurangan-kekurangan yang ada. Untuk kegiatan tindak lanjut masih dalam bentuk minimalisasi kekurangan atau tindakan antisipatif karena dianggap bahwa dampak yang ada terjadi karena masih barunya program ini dilaksanakan. Kegiatan evaluasi belum dilakukan dalam bentuk kegiatan yang sifatnya solving problem.

\section{KESIMPULAN}

Membangun sebuah kultur pada sebuah komunitas memang bukan hal yang mudah dan tentu saja memakan waktu yang cukup lama. Sehingga hasil yang diberikan pun bukan sebuah hasil yang instan. Diperlukan intensitas, kerjasama dan kegigihan yang tinggi agar sebuah program dapat tercapai dengan baik. Kekurangan-kekurangan yang muncul dalam pelaksanaan kegiatan pada program pengembangan kultur literasi ini meskipun masih diselesaikan dalam bentuk antisipatif namun telah menunjukkan keseriusan pengelola secara konsekuen menjalankan manajemen pengembangan kultur literasi di MTs Negeri Kota Batu ini. 


\section{REFERENSI}

Baynham, M. (1995). Literacy practices: investigating literacy in social contexts. London: Longman.

Beers, C. S., Beers, J. W., \& Smith, J. O. (2009). A Principal's Guide to Literacy Instruction. Guilford Press.

E.Waruwu, F. (2010). Membangun Budaya Berbasis Nilai. Yogyakarta: Kanisius.

Kern, R. (2000). Literacy and Language Teaching. OUP Oxford.

Kristiawan, M. K. (2017). Manajemen Pendidikan. Jakarta: Deepublish.

Madaus, G. F., Scriven, M., \& Stufflebeam, D. L. (2012). Evaluation Models: Viewpoints on Educational and Human Services Evaluation. Springer Science \& Business Media.

Mullis, I., Martin, M., Kennedy, A., \& Foy, P. (2007). Progress in International Reading Literacy Study (PIRLS) 2006: Highlights from Scotland's Results. Scottish Government.

Tribunnews. (2017, Mei 15). Memprihatinkan, Ternyata Minat Baca Indonesia Duduki Peringkat 60 dari 61 Negara. Diambil 10 Januari 2018, dari http:/ / www.tribunnews.com/regional/2017/05/15/memprihatinkanternyata-minat-baca-indonesia-duduki-peringkat-60-dari-61-negara

Wiedarti, P. (2016). Desain induk gerakan literasi sekolah. Jakarta: Direktorat Jenderal Pendidikan Dasar dan Menengah. 